\title{
The Consequences of Natural Crises on Tourism Destinations: A Case Study of the City of Petra in Jordan
}

\author{
Bashar Shukry Farhan Maaiah $^{1}$ \\ ${ }^{1}$ Petra College for Tourism and Archaeology, Tourism Marketing, Al-Hussein Bin Talal University, \\ P.O. Box 20 Ma'an, Jordan
}

\begin{abstract}
The main aim of the current study is to provide a comprehensive understanding of the proper knowledge required to solve and counteract the harmful effects of natural crises occurring in tourist destinations in Jordan, specifically at the site of Petra. In order to fulfill the aim mentioned above, an empirical approach was adopted to examine and analyze the deficiencies that exist in the current plans used by both public and private sectors in Jordan to face the negative effects of natural crises that strike Petra. Finally, a proposed model will be presented to the sectors mentioned above with recommendations on how these deficiencies can be eliminated to provide better crises management in Petra.
\end{abstract}

\section{Introduction}

Every day, the media around the world over-flows with news of accidents and disasters that is occurring worldwide. The recent global assessment report on natural disasters in the United Nations shows that the number of natural disasters, economic losses, and the number of people affected are increasing at a rapid rate, faster than risk reduction can be achieved [1,2,3].

However, news concerning natural disasters have become very familiar in the media, which can seriously affect tourism, especially when accompanied with a large number of casualties [4]. Volcanoes, landslides, tsunamis and floods are natural disasters that occur regularly, and they always leave behind destruction, devastation and grief. Governments are concerned regarding the potential economic implications of increasing risks, particularly the consequences regarding insurance systems for companies and households [5,6,7]. Though, humans have tried to reduce the impact of the destruction caused by hurricanes, earthquakes and fires by developing alerts, but were often powerless $[8,9,10]$. These incidents are felt strongly by all domestic institutions and surrounding communities even if they are not directly affected by the incidence itself.

With regard to tourism, there are intense connections and interdependencies between the most popular tourist destinations worldwide, which can lead to successive waves of negative effects on them if there was a disaster $[11,12,13]$

Professional workers in the tourism sector have become more vulnerable, and many of them were affected. As a result, they have become more concerned with the crises and disasters that occur around them $[14,15,16]$. Disastrous events and their adverse effects would economically threaten, weaken or destroy the competitiveness of tourist destinations $[17,18,19]$. However, an analyses performed by insurance companies on past disaster losses show that direct economic losses have increased, particularly the losses that are due to weather-related hazards such as floods, droughts, storms and 
landslides [20,21,22]. In the year 2000, there were great occurrences of disasters and massive migrations of birds which affected many world tourist destinations. Floods causing billions of dollars of losses dominated the natural catastrophe statistics for the first half of the year 2013 [23,24,25]. These events contributed in alerting all tourism stakeholders (producers, investors, shareholders and even customers) since the process of blossoming the tourism industry is globally linked to global peace and security $[26,27,28]$.

The vulnerability of the human population to weather and climate extremes is increasing as more people and more property are relocating to areas prone to such extreme weather conditions [29,30,31]. However, the tourism industry has worked to manage the crises, disasters and their negative effects in the past decade [32,33]. The tourism industry has evolved; and therefore, it overcame the crises that occurred by focusing on the nature of the crisis or disaster. Thus, this would enable the industry to be proactive in managing and dealing with the crises and disasters before they occur or that might occur later in the future.

This paper summarizes specifically, the theoretical understanding of crisis management in the city of Petra. To the best knowledge of the author of the current study, this is the first study that investigates crises management in the city of Petra as a touristic destination.

\subsection{Background}

The region of Petra is located on 1753.11 hectares and includes six local regions (Dlagh, Alrajv AlTaybeh, Wadi Musa, Umm Sihon and Baydah ). The region of Petra has 18.511 inhabitants according to estimates by the Department of Statistics for the year 2013. There are also six wellmaintained local road networks linking the six regions of populations mentioned above.

The most important public institutions such as banks and specific administrative services are concentrated in Petra. Furthermore, the region of Wadi Musa has the best tourist and administrative infrastructure. Wadi Musa is also considered as the main point in the region of Petra link, from where most buses for different regions in Jordan depart (Table 1).

Table 1. Visitors of Wadi Mousa Between 2011-2012 (Source: Department of Statistics)

\begin{tabular}{|c|c|c|c|}
\hline year & Jordanians & foreigners & Relative change11/15 \\
\hline 2011 & 121.346 & 508.518 & -6.2 \\
\hline 2012 & 113.856 & 522.29 & 2.7 \\
\hline
\end{tabular}

The geographical area of Petra is very important for the development of tourism infrastructure for the surrounding underdeveloped regions. According to the Commission of the city of Petra, the region has been classified into three main areas which are A, B and C (serving as the tourist route between Wadi Musa and Al-Taybeh). Area (A) which is near Wadi Musa has many sites protected from any human or tourist construction, so as to protect the environment, its topography and natural beauty. Area (B) is considered as a sensitive location that allows strictly regulated modern development. Area (C) is close to Al- Taybeh and is considered as a less sensitive site where limited development is allowed under less stringent laws.

The Community of Wadi Musa has developed a cultural tourism pattern which is based on the city and the valley of Moses. The density of tourists is the largest in the region and helps to generate local market traders, restaurants, bars, and a variety of important attractions. Thus, it should be noted that the city of Petra is classified or regarded as a cultural and an international heritage. All the elements mentioned above helped the city of Petra to be one of the largest and oldest world heritages, with a history that extends to the second century BC.

Furthermore, the author of the current study suggests that it is a must to explore the negative aspects of natural crises, namely floods in arid mountainous regions as an example of destructive natural disasters that occur in Petra. A flash flood can be instantly generated during or shortly after a 
rainstorm. Experienced managers believed that the existing plans for the protection of tourism infrastructure in the city of Petra from the dangers of flooding are inadequate and must be improved.

In 2011 and 2012, there was a disaster of flood water in Wadi Mousa which caused the cessation of many tourist and administrative activities and traffic interruption for a period of more than 48 hours in the region (Table 2)

Table 2. Monthly Bookings of All Hotels in Wadi Musa (Source: Jordanian Ministry of tourism)

\begin{tabular}{|c|c|c|c|c|c|c|c|c|c|c|c|c|c|}
\hline Year & Dec & Nov & Oct & Sep & Aug & Jul & Jun & May & Apr & Mar & Feb & Jan & Total \\
\hline 2009 & $40 \%$ & $61 \%$ & $82 \%$ & $49 \%$ & $32 \%$ & $21 \%$ & $28 \%$ & $56 \%$ & $76 \%$ & $60 \%$ & $33 \%$ & $27 \%$ & $49 \%$ \\
\hline 2010 & $47 \%$ & $76 \%$ & $92 \%$ & $66 \%$ & $36 \%$ & $32 \%$ & $40 \%$ & $66 \%$ & $82 \%$ & $75 \%$ & $42 \%$ & $28 \%$ & $57 \%$ \\
\hline 2011 & $9 \%$ & $18 \%$ & $20 \%$ & $10 \%$ & $4 \%$ & $6 \%$ & $10 \%$ & $30 \%$ & $56 \%$ & $52 \%$ & $34 \%$ & $33 \%$ & $38 \%$ \\
\hline 2012 & 0 & 0 & 0 & 0 & 0 & 0 & 0 & $9 \%$ & $17 \%$ & $18 \%$ & $13 \%$ & $9 \%$ & $13 \%$ \\
\hline
\end{tabular}

The local government does not have any significant action plan to minimize the impact of the crisis on the tourism sector. This has directly led many tour operators to cancel trips for the 2011 season (Table 1) which resulted in falling incomes of workers in the tourism sector and the city of Petra itself. In fact, at least $65 \%$ of the income of the local population in the town of Wadi Musa depends on tourism. This prompted the government represented by the Ministry of Tourism, to use methods and techniques to save the tourist image of the city of Petra. However, this was done without taking into account the negative image displayed after floods occurred, and especially since the media tends to exaggerates catastrophic phenomena (Table 3).

Table 3. Differences in Wadi Mousa Arrivals between 2009-2011. (Source: Jordanian Ministry of Tourism)

\begin{tabular}{|c|c|}
\hline Differences of arrivals per year in Wadi & Percentage occupancy hotels \\
Musa & $49 \%$ \\
\hline 2009 & $57 \%$ \\
\hline 2010 & $38 \%$ \\
\hline 2011 & \\
\hline
\end{tabular}

\subsection{References to Literature}

The main sources of attraction for a tourist site are items related to tourism demand at this site. These sources determine the greatest attraction and at the same time can determine whether or not a visit can be made to such a destination [34]. The elements mentioned above have been classified by the current study researcher into seven groups: 1 - tourist structure (infrastructure and supra- structure); 2 tourism services and tools presented in the tourism site; 3 - marketing optimized for tourism products; 4 - the ability of workers in the tourism sector to offer their products; 5 - destination security and public safety for visitors; 6 - touristic recreational activities; 7 - leisure events.

The world has experienced unprecedented high-impact climate extremes during the 2001-2010 decade, which was the warmest since the start of modern climate measurements in 1850 [35]. The decade which ended in 2010 was an unprecedented era of climate extremes, as evidenced by heat waves in Europe and Russia; droughts in the Amazon Basin, Australia and East Africa; and huge storms such as Tropical Cyclone Nargis and Hurricane Katrina [36]. Exposure and vulnerability to natural hazards is increasing as more people and physical assets are located in areas of high risk. Tourism Attractions accompanied by marketing plans has significantly contributed to the success of a tourist destination. Beirman (2003) presented a detailed analysis of the most important crises that may occur naturally or are human-induced and the effect they have on the world tourism process. This 
detailed analysis assisted the World Tourism Organization to significantly enhance its efforts in recent years to help nations all over the world to effectively deal with the catastrophic effects of disasters and crises. The simple assumption of risk (according to the defensive principle) increased costs for commercial transactions at the global level for the long-term, as it had the greatest impact on the global strategic decision-making in economic development [37].

Insurance statistics reveal that out of the 905 documented loss events in 2012, 840 (93\%) were weather-related, i.e. storms, floods and climatological events such as heat waves, cold waves, droughts and wildfires after earthquakes [38]. Since 2005, studies have identified that there is a significant reduction in the number of tourists and hotel booking in areas prone to crisis or natural disaster. Political problems and terrorism are the only man-made elements that can affect the assessment of the degree of safety of a tourist site in a country. Since then, media coverage of crises and disasters had a major negative impact on the tourism site affected; however the negative impact may also extend to other nearby or distant areas [39].

Accordingly, it was noted that many tourist sites present a significant safety risk, and therefore should not be visited. When authorities in some countries warn their residents from visiting specific destinations, this will negatively affect several attractions [40]. As it is known, media declaration regarding the crisis in a tourist destination would result to a large number of cancelation of reservations within a few hours, such as hotel booking, transport, cultural activities, sports and many other services. Therefore, it can take years or even decades to build a new image for such tourist destination following the occurrence of a crisis [41]. Numerous studies have worked on the analysis of crises and several models and solutions have been developed. Nevertheless, natural crises occur in different ways and they often strike directly.

\section{Methodology}

In order to gather the necessary information concerning the natural crises in Jordan, particularly in the city of Petra, interviews and questioners for both public and private sectors in charge of dealing with natural crises in Jordan have been utilized. A total of 30 questions were formulated regarding strategies, methods and plans proposed to prevent the natural crises which often strike the city of Petra. The author found out that since the year 2000, three natural disasters stroked the city of Petra, and till this present time, there are no effective strategies or plans formulated or presented to prevent or manage the negative effects of these natural crises.

\section{Data Analysis}

The proposed model to counteract and prevent the negative effects of natural crisis in the city of Petra, to be presented to the public and private sectors in charge of dealing with natural crisis in Jordan, is a multi-step approaches that was adopted by Avraham and Ketter [40] to restore confidence in a tourist destination.

- The first step is a preliminary analysis of the crisis, clients and the properties of the destination in question (CAP analyzes: $\mathrm{C}$ identifies the Crisis, A identifies the Affect of rumors and $\mathrm{P}$ identifies the tourist Place).

- The second step explains the role of traders who must determine the objectives of the tourist agency and favorable atmosphere for tourism to meet the touristic demand.

- The third step is to choose the marketing strategy or a combination of strategies, which were previously identified in the preliminary analysis of tourist objectives. The choice can be made through three groups of integrated media strategies. The first group includes tourism professional workers that focus on their media tools which will provide information to the target client, the second includes tourism professional workers that utilize their media tools to attract the target customer, and finally the third group includes tourism professional workers who focus their practices on media information or messages intended to be delivered to the target customer. The above strategy is called (SAM) where 
S: identifies the source, A: identifies the Audience and M: identifies Message from any source that provide information.

The founders of the strategy (SAM) analyzed ways to fight and prevent media abuse and present appropriate image of a tourist attraction. To activate the role of the media which always focuses on the natural disasters that could negatively affect the tourist sites, and at the same time ensure that the site is not affected by the media machine, it is important to focus on two main strategies. The first strategy (come and watch yourself), means that the tourism destination is safe and welcoming to tourist activities. The second strategy is to use celebrities as an alternative source of information for the delivery of a positive image of a tourist destination to the target audience.

The message strategy relies on the following steps:

1 - Ignore the crisis and its impact and pretend that there is no sign of crisis to minimize the extent of damage;

2 - To transfer the crisis to another distant place from a tourist destination;

3 - To minimize the focus on the negatives and focus on the positive aspects;

4 - To face all the rumors which create a negative image of a tourist destination

5 - To focus on the importance of sports and cultural activities, as well as the rehabilitation of the tourist destination in the media, in addition to giving an image of a quiet location in order to give a positive image of a tourist destination;

6 - The use of media facilitated propaganda and promotion to deliver messages that demonstrates the safety of the site through the release of numerous films in the media and using celebrities who live safely and peacefully in this environment for long periods of time. Therefore, this will support and enhance marketing efforts to spread a positive image of the site;

7 - To fight the negative image of a tourist destination through the introduction and adoption of advertisement using many distribution companies, and by using all efforts to reverse the negative image of the destination and promote a positive existing reality;

9 - Eliminate the rumors spread by the media which could result to negative images of tourist destinations by ridiculing such negative publicity and by guiding the tourists' attention to the positive aspects.

Finally, the following are suggested strategies that report information intelligently and positively to tourists:

1 - The first strategy is to use nationalists and patriots to speak only positively of their country and the tourist destination;

2 - Change the target tourists. As it is the custom, the image of the tourist destination is formed and formulated by many factors that can have a negative impact on a destination and at the same time a positive impact on another.

Planning is essential to control the negative effects of the tourist destination image which can be immediate or later in the future [43] and this should be integrated into the management of the tourism industry in a country. To do this, policy-makers should focus on comprehensive tourist destination management which will unite all marketing efforts, both in public and private sectors, and even activities that are related to crisis management. Partnership efforts and cooperation should include government agencies [44], local tourist organizations, foreign tour operators and local tourist offices. This would ensure the success of the reconstruction of the image of a tourist destination and also help to overcome the impact of the negative media publicity.

Managers of tourism destinations are working hard to optimize the tourist destination image [45], therefore they help in the creation of distinct identity for a tourism destination. This encourages an increasing ratio of competition between countries to attract investors, tourists and positive media coverage. In addition, the more the investment is, the more the need for effective strategies to avoid reducing the positive image of the destination [46]. 


\section{Recommendations}

The researcher recommends that future research in this area should include a large-scale quantitative and qualitative analysis of natural crises in other touristic Jordanian sites. Also, it is recommended to have a comparative work in a similar context within different countries to observe the numerous similarities and dissimilarities related to the crises strategies and plans. Therefore, this would prove beneficial for the possible validation of the findings in the current study in comparison with other locations particularly in other Middle East regions that may experience somewhat different touristic destination environments. Nevertheless, this study may be considered as a step towards developing a more systematic cooperation between the public and private sectors in Jordan in order to have a better and more developed knowledge of facing the negative impact of natural crises in Jordan.

\section{Conclusion}

In the last decade and all over the world, the economic and social policies are volatile and unstable. The tourism sector is a very sensitive sector to various crises particularly in developed countries such as the United States, Great Britain and Europe which are increasingly trying to control their economic resources such as tourism.

Today, the proliferation of massive information technology and globalization have allowed all media, advertising and publishing firms to produce images and movies that could affect any destination, where it is not even possible to make a final arrangement of tourist activities in record time in case of crises. Crises and accidents that occur in tourist areas occur unexpectedly, which will increasingly impact the local and international tourist flows. This leads to lower prices for goods and services, and significantly reduces the level of employment and service quality in a short period of time.

Tourist destinations are spending huge sums of money, in order to obtain a unique tourism image with the aim of creating a brand title and attaining commercialization of a strong and attractive tourist destination. These expenses are high because they positively encourage the level of competition between countries to attract investors, tourists and media. In addition, the higher the investment rate, the higher will be the need for effective strategies to ensure a positive image of the destination. Thus, it is necessary for responsible tourism operators in a country to be aware, knowledgeable and ready to face any situation or emergency or crises that may arise in tourist destinations.

This affirms that the organizations and professional workers in charge of the tourism sector in Jordan must respect their responsibilities in facing natural crises especially in Petra. In addition, public and private tourism sectors in Jordan should take into account the results and analysis of the current study with the goal of developing better strategies and plans to face the negative impact of natural crises affecting the city of Petra in particular, as well as other tourist sites in Jordan. The managers of tourism sites must have the ability and willingness to participate in a partnership and continuous communication with all parties that are involved in tourism in Jordan. This includes constructive and positive interaction between the private and public sectors, enabling all parties to act as decisionmakers, without resorting to individual decisions which can lead to fragmentation and lack of discipline. In addition, they should be able to benefit from past experiences in fighting natural crises and the results that were obtained which could provide means to reach an effective solution for future crisis.

\section{References}

1. UN-ISDR, Risk and poverty in a changing climate: Invest today for a safer tomorrow. United Nations international strategy for natural disaster reduction global assessment Rep. On disaster risk reduction, 207 (2009)

2. E. Avraham, E. Ketter, Will we be safe there? Analyzing strategies for altering unsafe place images. Place Branding and Public Diplomacy, Palgrave Macmillan Ltd, 4, 196-204 (2008b) 
3. A. Pritchard, N. Morgan, Evaluating vacation destination brochure images: The case of local authorities in Wales. Journal of Vacation Marketing 2, 1, 23-38 (19985)

4. $\quad$ F. Knight, Risk, Uncertainty and Profit. Boston, MA: Houghton Mifflin Company (1948)

5. W.J.C.J.M, Botzen van den Bergh, L. M. Bouwer, Climate change and increased risk for the insurance sector. A global perspective and an assessment for the Netherlands. Nat. Hazards 52, 577-598 (2010)

6. B. Bramwell, L. Rawding, Tourism marketing images of industrial cities. Annals of Tourism Research 23, 1, 201-221 (1996)

7. R.W, Butler, The concept of tourist area cycle of evolution: Implication for management and resources. Canadian Geographer 24, 5-12 (1980)

8. P. Oliveira, P.T, Pereira, Who values what in a tourism destination? The case of Madeira Island. Tourism Economics 14, 1, 155-168 (2008)

9. $\quad$ C.P, Barros, L.P. Machado, The length of stay in tourism. Annals of Tourism Research 37, 692706 (2010)

10. R. Camprub1, Tourism image fragmentation: the case of Perpignan. Tourism and Hospitality research: Sage (2011)

11. J. Grainger, I. Crouch Geoffrey, Reconceptualising Destination Image Using Perceived Risk.

Hellenic Open University, Crete, June, 15-18 (2006)

12. C.A, Gunn, Vacation scape Designing Tourist Regions. New York, NY: Van Nostraud Reinhold (1988)

13. G. Larsen, V. George, The Social Construction of Destination Image - A New Zealand Film Example. Working Paper No 4, 1. Bradford University (2004)

14. B. Richardson, Crisis management and management strategy. Time to "Loop the Loop"?".

Disaster Prevention and Management 3, 3, 59-80 (1994)

15. S. Pike, C. Ryan, Destination positioning analysis through a comparison of cognitive, affective, and conative perceptions. Journal of Travel Research 42, 333-342 (2009)

16. E. Laws, Tourism Destination Management: Issues, Analysis and Policies. London: Rout ledge (1995)

17. J.R.B. Ritchie, G.I. Crouch, The competitive destination: A sustainable tourism perspective. Cambridge, MA: CABI (2003)

18. N. Telisman-Kosuta, Tourism destination image. In: Witt SF and Moutinho L (eds) Tourism Marketing and Management Handbook. Cambridge: Prentice Hall, 557-561 (1989)

19. S.Baloglu, K.W. McCleary, A model of destination image formation. Annals of Tourism Research 26, 4, 808-889 (1999)

20. R.E. Munich, Topics Geo natural catastrophes 2009: Analyses, assessments, positions. Munich reinsurance company Rep., 40 (2010)

21. M.A. Cea, Analisis multivariante. Teorra y practica en la investigacion social. Madrid:

Editorial Sintesis (2004)

22. W.C. Gartner, Image formation process. Journal of Travel and Tourism Marketing 2,2,191-215 (1993)

23. R.E. Munich, Floods Dominate Natural Castrophe Statistics in First Half of 2013, Press Release, 9 July ,Munich Reinsurance, Munich, Germany (2013a)

24. J.L. Crompton, Structure of vacation destination choice sets. Annals of Tourism Research 6 ,408-424 (1992)

25. C.A. Gunn, Vacationscape. Designing Tourist Regions. Washington, DC: Taylor and Francis/University of Texas (1972)

26. M. Hall, J.T. Dallen, D.T. Duval, Safety and Security in Tourism: Relationships, Management, and Marketing. London (2004), Hawthorne Hospitality Press (2004)

27. A. Molina, A. Esteban, Tourism brochures: Usefulness and image. Annals of Tourism Research 33,4, 1036-1056 (2006)

28. M.G. Gallarza, I, Gil, H. Caldero'n, Destination image - Towards a conceptual framework. Annals of Tourism Research 29, 1, 56-78 (2002) 
29. R.E. Munich, Topics GEO—Natural Catastrophes 2012: Analyses, Assessments And Positions. Munich Reinsurance, Munich, Germany (2013b)

30. R. Govers, F.M. Go, FM Cultural identities constructed, imagined and experienced: A 3-gap tourism destination image model. Tourism 52, 2,165-182 (2004)

31. B. Faulkner, Towards a framework for tourism disaster management. Tourism Management 22 , 135-147 (2001)

32. D. Pearce, Tourist Development. New York, NY: Longman (1989)

33. WMO, Global Climate 2001-2010: A Decade of Climate Extremes-Summary Report. WMO no. 1119, World Meteorological Organization, Geneva, Switzerland (2013)

34. H. Kim, S.L. Richardson, Motion Picture Impacts on Destination Images. Annals of Tourism Research 30, 1, 216-237 (2003)

35. A. Pritchard, N. Morgan, Selling the Celtic Arc to the USA: A comparative analysis of the destination brochure image used in the marketing of Ireland, Scotland and Wales. Journal of Vacation Marketing 2, 4, 346-365 (1996)

36. G.R. Dowling, R. Staelin, A model of perceived risk and intended risk-handling activity. The Journal of Consumer Research 21, 1, 119-134 (1994)

37. IPCC, Managing the Risks of Extreme Events and Disasters to Advance Climate Change Adaptation. In: C.B Field, V. Barros, T.F Stocker, D. Qin, D.J Dokken, K.L Ebi, M.D Mastrandrea, K.J Mach, G.K Plattner, S.K Allen, M. Tignor, P.M. Midgley (Eds.), A Special Report of Working Groups I and II of the Intergovernmental Panel on Climate Change, Cambridge University Press, Cambridge, UK, and New York, NY, USA, 582 (2012)

38. S.F. Sonmez, Tourism, terrorism, and political instability. Annals of Tourism Research 25, 416-456 (1998)

39. J.C. Henderson, Responding to natural disasters: Managing a hotel in the aftermath of the Indian Ocean Tsunami. Tourism and Hospitality Research 6, 1. ABI/INFORM Global (2005)

40. E. Avraham, E. Ketter, Media Strategies for Marketing Places in Crisis: Improving the Image of Cities, Countries and Tourist Destinations. Oxford, UK : Butterworth Heinemann (2008a)

41. L. Barton, Crisis management: Preparing for and managing disaster. The Cornell Hotel and Restaurant Administration Quarterly 35, 3, 59-65 (1994)

42. S. F. Sonmez, Y. Apostolopoulos, P. Tarlow, Tourism in Crisis: Managing the Effects of Terrorism. Journal of Travel Research 38, 1, 3-9 (1999)

43. C. Nevenka, Tour operators and destination safety. Annals of Tourism Research 29, 2, 478496 (2002)

44. T. Drabek, Disaster Evacuation and the Tourist Industry. Boulder CO: Institute of Behavioral Science, University of Colorado (1994)

45. R. Camprubi, J. Guia, J. Comas, Destination networks and induced tourism image. Tourism Review 63, 2, 47-58 (2008)

46. B. Maaiah, Les voyagistes du sud dans la mondialisation: Le cas de RAJ (La compagnie Royal Air Jordanian UPMF, France (2008) 